\title{
Assessing the Sustainability of Small Farmer Natural Resource Management Systems. A Critical Analysis of the MESMIS Program (1995-2010)
}

\author{
$\underline{\text { Marta Astier }}^{1}, \underline{\text { Luis García-Barrios }}^{2}, \underline{\text { Yankuic Galván-Miyoshi }}^{3,4}$ Carlos E. González-Esquivel $^{5}$, and Omar R. Masera $^{5}$
}

\begin{abstract}
Sustainability assessment oriented to improve current systems and practices is urgently needed, particularly in the context of small farmer natural resource management systems (NRMS). Unfortunately, social-ecological systems (SES) theory, sustainability evaluation frameworks, and assessment methods are still foreign not only to farmers but to many researchers, students, NGOs, policy makers/operators, and other interested groups. In this paper we examine the main achievements and challenges of the MESMIS Program (Spanish acronym for Indicator-based Sustainability Assessment Framework), a 15-year ongoing effort with impact in 60 case studies and 20 undergraduate and graduate programs mainly in Ibero-America that is attempting to cope with the stated challenges. The MESMIS experience shows that it is possible to conduct sustainability assessments in the context of small farmers through a long-term, participatory, interdisciplinary, and multi-institutional approach that integrates a solid theoretical background, a field-tested operational framework, learning tools specifically devised to facilitate the understanding of sustainability as a multidimensional and dynamic concept, and a growing set of case studies to apply to and get feedback from users. Specifically, through the dissemination of the MESMIS assessment framework in a large set of case studies in a contrasting set of social-ecological contexts, we have been able to: (a) characterize the NRMS, their subsystems, and their main interactions; (b) link attributes, i.e., general systemic properties, with sustainability indicators to assess critical socioeconomic and environmental aspects of the NRMS; (c) integrate indicators through multicriteria tools and to expose the multidimensional aspects of sustainability; (d) propose an initial multiscale assessment to articulate processes and actors at different spatial scales; (e) develop multimedia learning tools, i.e., Interactive-MESMIS, to help users understand dynamic concepts, trade-offs, and counter-intuitive behavior; and (f) promote participatory processes through role-playing games and agent-based simulation models. Key challenges are related to the need to conduct long-term longitudinal studies that fully capture system dynamic properties while at the same time actively involving relevant stakeholders through creative and lasting participative processes. We outline an improved assessment framework that should help move the program in this direction.
\end{abstract}

Key Words: complex systems; Latin America; natural resource management; small farmers; social-ecological systems; sustainability assessments

\section{INTRODUCTION}

Sustainability was first linked to a concept of sustainable development that aimed to incorporate environmental concerns within the framework of conventional economic growth (WCED 1987). Relatively simple frameworks (Stockle et al. 1994, Mitchell et al. 1995) and long lists of loosely bundled "sustainability indicators" (UN 1996) were used for short-term, rapid assessments. Since then, the concept, goal, and tools have diversified, evolved, and become more sophisticated. This has produced: (1) general theories of sustainability of complex social-ecological systems (Holling and Gunderson 2002, Young et al. 2006, van Noordwijk 2009); (2) frameworks that integrate ecological and social drivers across scales (e.g., Ostrom 2009); (3) models of regime shifts in social-ecological systems (SES; e.g., Scheffer 2009); (4) relevant indicators (e.g., Astier and González 2008); (5) multicriteria evaluation methods (Mayer 2008); (6) involvement of relevant stakeholders (e.g., Collectif ComMod
2006, Daré et al. 2008, Janssen et al. 2010); and (7) case studies at the local, regional, national, or global level (Sturtevant et al. 2007, Astier et al. 2011).

Although research on natural resource management (NRM) at the local level is vast and diverse, most formal sustainability analyses are only applied to regional, national, or global scales, with emphasis on specific sectors, e.g., forestry, agriculture, industry, and so on. Approaches for "sustainability in place," with emphasis on very local contexts and actors, are crucial to underpin bottom-up adaptive comanagement strategies (Manuel-Navarrete et al. 2006). However, these approaches remain largely overlooked. Livelihoods of millions of smallholders in developing countries are inextricably and tightly dependent on resources and services provided by natural ecosystems. These stakeholders are often marginalized yet strategic in this process (García-Barrios and GarcíaBarrios 1992, Boege 2009). Poverty and unsustainable natural resource management practices remain endemic to several

\footnotetext{
${ }^{1}$ Centro de Investigaciones en Geografía Ambiental, Universidad Nacional Autónoma de México, ${ }^{2}$ El Colegio de la Frontera Sur, ${ }^{3}$ Grupo Interdisciplinario de Tecnología Rural Apropiada, Universidad Nacional Autónoma de México, ${ }^{4}$ Department of Geography, Michigan State University, ${ }^{5}$ Centro de Investigaciones en Ecosistemas, Universidad Nacional Autónoma de México
} 
peasantry territories. However, initiatives for improving livelihood strategies are also emerging through the creativity and motivation of local stakeholders and the support from external organizations and governments. Such initiatives often involve recovering traditional management practices for soil conservation and restoration, development of efficient and clean technologies suitable for local cultural practices and preferences, and integrated agrosilvopastoral systems, among other options.

Nowadays, however, contrasting NRM strategies, e.g., communal vs. private access; agricultural systems with low vs. high industrial inputs; monocultures vs. highly diverse polycultures, coexist in the same small farmer, or smallholder, region, locality, or household (García-Barrios et al. 2009a). Under these circumstances, the critical question that needs to be answered is: Will small farmers respond to the present challenges and global social-ecological change by developing sustainable NRM practices, production systems, rural livelihoods, and governance schemes that will drive them out of poverty traps while enabling critical ecological processes to change but remain functional? Answers to this question are diverse, highly contrasting, and subject to strong debate (Grau and Aide 2008, Perfecto et al. 2009, Brussaard et al. 2010, Perfecto and Vandermeer 2010).

We argue that, to answer this and other related questions, and to bridge theory, empirical studies, and social action we need long-term research, education, and policy building programs that enable small farmers, and other related stakeholders, to continuously assess the sustainability and the dynamic socialecological consequences of their NRM decisions. Unfortunately, SES frameworks, sustainability evaluation, and assessment methods are still foreign not only to farmers but to most researchers, students, NGOs, policy makers/ operators, and other stakeholders.

During the past 15 years, a group of researchers from Mexican institutions and NGOs have made efforts to tackle the aforementioned challenges by developing an integrated research and development program named "MESMIS," a Spanish acronym for Indicator-based Sustainability Assessment Framework. The framework is adapted to small farmers, who constitute 63\% of farmland in Latin America (ECLAC 2009). In the context of MESMIS, small farmers are those who commonly hold diversified and small-scale farms (usually $<5$ ha, but the specific farm-size threshold depends on the country), employ family labor, and produce both subsistence and commercial goods, i.e., crops, livestock, forest products.

The MESMIS program simultaneously considers five strategic and interrelated goals: (1) to integrate the theory of complex systems into sustainability assessments; (2) to develop and update a comprehensive and coherent sustainability assessment framework that can allow stakeholders to make short- and long-term multicriteria comparisons of alternative NRM strategies; (3) to facilitate the learning processes by which stakeholders can understand, use, and give feedback on the concepts, tools, and outcomes of such assessments; (4) to validate the framework by promoting a number of case studies; and (5) to promote and facilitate the participation of all stakeholders in the assessment process.

In this article we present the conceptual approach of the MESMIS program, summarize its 15 years of experience, identify the main contributions and challenges in its implementation, and address areas of current and future development of the methodology according to five main components of our research approach: theoretical framework, operative structure, case studies, teaching and training, and participative processes. We briefly outline an improved iterative evaluation cycle directed to incorporate more fully the dynamic aspects of SES framework and the participation of stakeholders into sustainability assessments. We conclude by discussing the future challenges for assessing the sustainability of small farmer natural resource management systems (NRMS).

\section{THE MESMIS PROGRAM}

The MESMIS effort originated in the early 1990s in Mexico in the context of an initiative launched by the Rockefeller Foundation to foster alternative peasant NRMS. A critical need for the Rockefeller Program was to develop a sustainability assessment framework to address the following questions: Can small farmers respond to global socialecological changes through their NRMS? Are these farmers capable of creating functional and changing ecological processes that can at the same time alleviate poverty in their peasant communities?

From the work of Conway (1994), Gallopín (1997), and García (1994), among others, it was clear that a sustainability evaluation framework should go beyond approaches that focus on short-term economic and productive aspects, such as standard benefit-cost analyses. With this in mind, the MESMIS framework was developed, critically integrating key concepts regarding sustainable development, sustainability, systemic approaches, natural resource management, sustainability evaluation, and sustainability indicators (Masera et al. 1999, López-Ridaura et al. 2002).

In parallel, a first group of Mexican case studies was launched to validate the MESMIS methodology in very diverse social and environmental contexts (López-Ridaura et al. 2002). Two books were published (Masera et al. 1999, Masera and LópezRidaura 2000) that together with other outreach materials helped MESMIS to be quickly adopted as a framework for many more case studies in Latin America and a few in Spain and Portugal. The MESMIS framework was also gradually incorporated into more than 20 undergraduate and graduate 
programs in these countries through training workshops and courses continuously offered in Ibero-America. To date, more than 190 professionals and technicians from 12 countries, coming from the social and biological sciences, have graduated from MESMIS courses. Significant work has been done with local peasant communities and NGOs that allowed the MESMIS Program to link the theoretical aspects to concrete local realities, especially with small farmers.

So far, we have tracked more than 60 case studies conducted mostly in Latin America, but also in Spain, Portugal, and the United States (Speelman et al. 2007, Astier et al. 2011). Many of these studies have been carried out by people trained in the MESMIS courses. These rich experiences provided ample evidence that a place-based approach to sustainability assessment was not only useful to improve local and external stakeholder capability to address complex and contextdependent social-ecological problems, but also that small farmers urgently called for tools and methods to assess their own management strategies (Masera and López-Ridaura 2000, Astier and Hollands 2007). However, new challenges and a number of conceptual and methodological gaps became manifest.

To cope with these challenges, the MESMIS Program evolved in institutional terms, by including members from three research centers and an NGO. In structural terms, it simultaneously addressed five main tasks closely interlinked: (1) a theoretical framework, which is the conceptual referential background for the other four; (2) an operational structure, or assessment framework, which is the methodological framework that has been applied by users; (3) the case studies, which are promoted mostly by projects aiming at developing alternative peasant NRMS; (4) the teaching and training program for those applying MESMIS; and (5) a participatory framework supported by appropriate role-playing games, scenario simulators, and group dynamic exercises (Fig. 1). We describe and discuss in detail the contribution and challenges of the MESMIS Program within each of the program components.

\section{CONTRIBUTIONS AND CURRENT CHALLENGES FROM THE MESMIS PROGRAM}

We argue that the five-component structure of the MESMIS Program is key for sustainability assessments because succeeding in this task implies working simultaneously at a cognitive (knowledge-based); operational (method-based); pedagogic (learning/training-based); and evidence (validationbased) level. At a cognitive level, sustainability assessment requires moving beyond conventional disciplinary approaches, such as standard benefit-cost analyses, which conceive assessments as optimization problems aimed at obtaining a discernible "best solution." Sustainability assessments need to incorporate nonlinear dynamics, complexity, uncertainty, and multiscale, multidimensional aspects, and trade-offs between management strategies. Local communities' views and knowledge must truly be considered in the process. At an operational level, assessments need to provide a practical method that can be put in practice by nonexperts, to show the dynamics and multidimensionality of sustainability and provide concrete guidance on how to improve the socialecological performance of existing small farmer NRMS. At a pedagogic level, the program needs to provide the tools and develop the abilities to make the key concepts associated to sustainability understandable to users. Sustainability assessments need to promote the active participation of all stakeholders in case studies, and to facilitate the decision making process. The rich information and experience provided by these case studies should feed back into the rest of the components as part of an overall "adaptive" process.

Fig. 1. The MESMIS Program: its components and interactions.

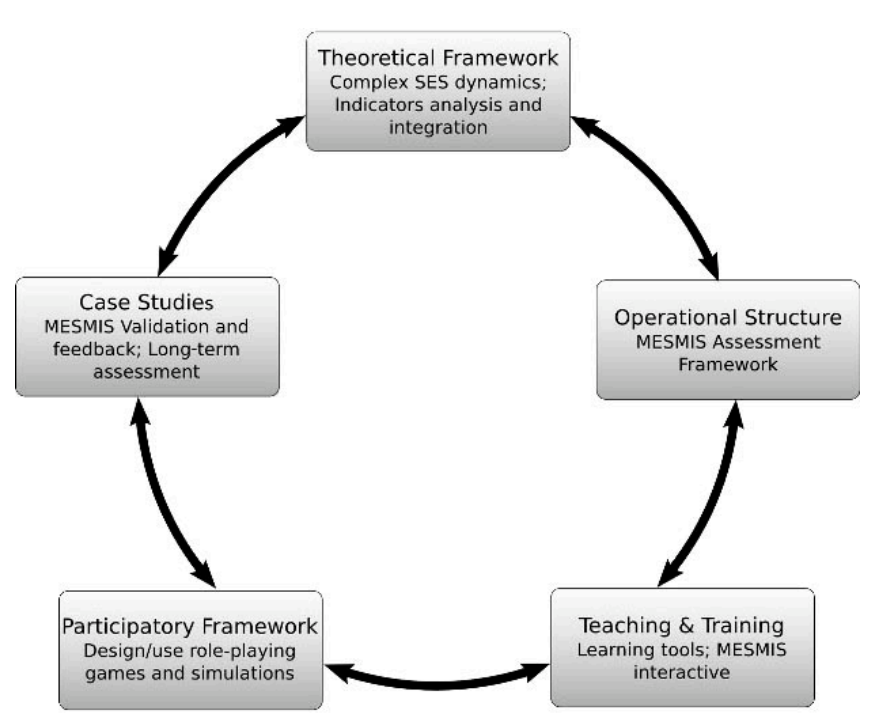

Theoretical framework: integrating SES dynamics into sustainability assessments

Integrating human and environmental dimensions into an operational framework for assessing small-scale NRMS requires bringing together a robust theoretical framework with user-friendly guidelines and tools applicable to different social-ecological contexts and evaluation team skills. To cope with this problem in the MESMIS framework, we have attempted to integrate two contrasting approaches to sustainability assessment: measurement-based and processoriented approaches. These two approaches are contrasted in Table 1. In measurement based approaches, shown in the first column, the goal is to decode the concept of sustainability into a set of quantifiable and independent set of indicators, which 
Table 1. Approaches to sustainability assessment.

\begin{tabular}{|c|c|c|}
\hline & Measurement-based approaches & Process-oriented approaches \\
\hline Theoretical conceptual framework & $\begin{array}{l}\text { Sustainable development targets and goals, } 3 \\
\text { dimensional approach (social, economic, } \\
\text { environmental) }\end{array}$ & $\begin{array}{l}\text { Dynamic systems } \\
\text { Complex adaptive systems }\end{array}$ \\
\hline Focus of attention & Benchmarking and ranking & $\begin{array}{l}\text { Identify and understand key drivers for } \\
\text { sustainability }\end{array}$ \\
\hline Main goal & $\begin{array}{l}\text { Judge success in relation to the attainment of a } \\
\text { target or goal }\end{array}$ & Explore potential future scenarios \\
\hline Methodological approaches & $\begin{array}{l}\text { Composite indices } \\
\text { Goal-oriented frameworks }\end{array}$ & System attribute-based frameworks \\
\hline Main instruments & Quantitative, reliable, and verifiable indicators & $\begin{array}{l}\text { Quantitative and soft modeling approaches, } \\
\text { Narratives }\end{array}$ \\
\hline Timing of the assessment & Ex post & Ex ante (planning) \\
\hline Duration & Short-term assessments & Long-term assessments \\
\hline Archetypical examples & $\begin{array}{l}\text { FESLM (Smyth and Dumanski 1993) } \\
\text { CIFOR framework (Prabhu et al. 1999) } \\
\text { Stockle et al. (1994) framework }\end{array}$ & $\begin{array}{l}\text { AMESH (Waltner-Toews and Kay 2005) } \\
\text { Resilience analysis (Walker et al. 2002) } \\
\text { Ostrom (2009) framework }\end{array}$ \\
\hline
\end{tabular}

can then be used to construct performance metrics to compare (rank) and assess (benchmark) progress toward sustainability. Most developed methodologies provide a set of guidelines for the decoding process, based on a Principles-CriteriaIndicators (PCI) hierarchical structure. Principles represent universal goals of sustainable development, like those established by the Agenda 21, which are progressively refined and translated into an equivalent, but place-specific set of indicators (Table 1).

Process-oriented approaches are also grounded on general, and universal, sustainability principles. However, sustainability is conceived as a systemic property rather than as a set of fixed goals (Clayton and Radcliffe 1996, Holling and Gunderson 2002). The endeavor is to identify key variables and process driving (un)sustainable dynamic regimes. Variables and processes can be represented through quantitative or qualitative models as well as narratives, because these representations help to inform on functional relationships between different domains of social-ecological systems. Such understanding is important to anticipate future outcomes from which society can take advantage of new opportunities or undertake preventive measures to deal with potential dangers. The evaluation is the means to develop plausible future scenarios and for planning adequate strategies to cope with them (ex ante assessment). Having long-term evaluation periods is a crucial aspect to better understand SES dynamics. The evaluation process is then forcibly conceived as a longterm continuous activity. Process-oriented frameworks rely on the emergent interdisciplinary fields of systems theory and complex adaptive systems (Table 1).

In the MESMIS Program, NRMS are seen as systems integrating social and environmental aspects currently thought of as SES (Berkes et al. 2002). These systems present multiple social and environmental subsystems and internal variables that exhibit complex behavior in time and space (Gunderson and Holling 2002, Ostrom 2009), such as positive and negative feedbacks, nonlinear responses, irreversible thresholds, emergent properties, and unpredictable/unexpected/unwanted results (Sterman 1994, Spector and Anderson 2000). Specifically, we consider the sustainability of SES as a process of "persisting by changing," which is achieved by the combination of short-term regulation and long-term adaptation to ever-changing biophysical and social conditions (Capra 2002). This form of persistence through adaptive cycles (Holling 2001) requires attributes such as stability, reliability, and resilience in the short and medium terms, but also instability, alternative equilibria, and adaptability in the long term (García-Barrios et al. 2008a, van Noordwijk 2009, Jackson et al. 2010). To operationalize the evaluation, we identify the most relevant attributes required by a specific NRMS, translate them into an appropriate set of indicators at different scales, and integrate them through multicriteria and graphical methods, such as AMOEBA diagrams. We have found that agent-based models and role-playing games are very effective for assisting this process of analysis and synthesis, and can help stakeholders understand and explore scenarios of SES sustainability with a complex-adaptive approach (García-Barrios et al. 2009b). We have also started to incorporate these tools successfully into the sustainability assessment processes (García-Barrios et al. 2008b, Speelman and García-Barrios 2010).

\section{Operational structure and case studies}

The MESMIS framework proposes four basic methodological premises and a cyclical sustainability assessment. The premises are: (1) sustainability of NRM systems is defined by seven general systemic attributes: productivity, stability, reliability, resilience, adaptability, equity, and self-reliance; (2) the assessment is context-based, and constrained to a specific spatial and time scale; (3) it is thought of as a 
participatory process requiring an interdisciplinary evaluation team; and (4) sustainability is not measured per se but in relative terms through the comparison of either two or more contrasting NRMS (cross-sectional assessment) or by assessing one NRMS through time (longitudinal assessment; Masera et al. 1999, López-Ridaura et al. 2002).

The cyclical sustainability assessment is based in a step-wise process that involves: (a) defining the context and the system under analysis; (b) deriving critical points and sustainability criteria, which are related to three areas of evaluation, i.e., environmental, social, and economic, and to the perceived strengths and weaknesses of the system under analysis; (c) deriving and measuring sustainability indicators along with their evaluation units and optimum values; (d) integrating the results by means of multicriteria graphic tools and analysis; and (e) communicating results from the assessment, which will in turn provide feedback to management decisions. Once the recommendations from the evaluation process are applied, a second stage is initiated, thus repeating the cycle. This procedure ensures a consistent relationship between sustainability indicators and general attributes (for a detailed description of the assessment framework see López-Ridaura et al. 2002).

We selected 25 case studies out of the 60 documented by our group to assess how the framework has been applied (Table 2 ). The case studies were chosen based on the quality and quantity of available data. We found that most case studies were conducted by academic institutions and, to a lesser extent, by NGOs and groups of farmers. The case studies were mostly executed independently from the MESMIS research team. Therefore, the operational structure was often adapted to satisfy the specific characteristics and objectives of the different case studies. Thirteen of these cases took place in Mexico, eight in Central and South America, three in Spain and Portugal, and one in the USA.

Intensive collaboration among researchers, technicians, and peasant families was required to define the system under analysis (López-Ridaura et al. 2002, Speelman et al. 2007, Ortiz-Ávila 2008). Usually the small farm integrates two or more subsystems, i.e., crop-livestock, agroforestry, croplivestock-forestry (Fig. 2). To a lesser extent systems are devoted only to cash crops, e.g., vineyards, cotton, agave, or extensive livestock, i.e., grazing systems. Because of this complexity, the evaluation usually focused on the subsystems containing the commercial crops/products, leaving aside subsistence crops and other elements, i.e., external or nonmonetary income, that also contribute to the livelihoods of the communities involved (Table 2). Usually two contrasting NRM systems, a conventional or reference system and an alternative one, are compared. In most cases, the alternative NRMS is based on agroecological principles, such as crop diversification, soil conservation, and external input reduction (Astier et al. 2011).
Most case studies connected indicators with systemic attributes (Fig. 3). It was easier, however, to derive indicators related with the productivity, both biological and economic, attribute, than those related with resilience, adaptability, and reliability. The derivation of some indicators, e.g., biodiversity $=$ stability and resilience, was more axiomatic than based on empirical demonstration and/or dynamical analysis. Different dimensions of sustainability were integrated into one set of indicators to achieve a balance without oversimplification (Table 2; Valentin and Spangenberg 2000).

Indicators were integrated using AMOEBA graphs, which proved very useful to highlight the multidimensional character of NRMS and also to communicate sustainability in a more operational and appropriate way than aggregated indices. This analytical tool helped farmers think about their management strategies in a holistic way (Galván-Miyoshi 2008). Most AMOEBAS were used to show the state of the systems assessed at a particular point of time. However, in some cases the AMOEBA graph was also used as an innovative monitoring tool, i.e., for ex post analysis of the time evolution of the indicators selected during the assessment (Fig. 4). Only a few case studies explored long-term and trade-off analyses (See the Appendix).

Even though specific participatory techniques and tools were used in each step of the assessment cycle (Ortiz-Ávila 2008), in many case studies the assessment teams struggled to incorporate dynamic concepts into the evaluation. Nevertheless, in seven cases the stakeholders had outstanding participation in all steps of the evaluation (Table 2). Most of the case studies involved a comparison of resource management strategies across farms within a community. A small set of case studies explored multiscale assessments, from farm to region, by defining specific objectives for each stakeholder at each relevant geographical scale, deriving scale-dependent indicators, and linking them using functional relationships (López-Ridaura 2005, López-Ridaura et al. 2005).

Only one evaluation cycle was performed in the great majority of case studies. One of the few exceptions was the work of Martínez (2005) in Sinaloa, Mexico, where an alternative crop-forestry-grazing system, based on tropical legumes and semifeedlot silage, was compared against a conventional system over a nine-year period (Fig. 4; Martínez 2005, Astier et al. 2011). Analysis of system dynamics and trade-offs between attributes and indicators were not addressed in any of the reviewed case studies.

\section{Teaching and training: development of interactive learning tools}

Learning tools were designed to improve the courses and effectiveness of training workshops in the last six years. A first compilation of these tools was integrated in "InteractiveMESMIS." Highly graphic, fun, and pedagogic interactive 
Table 2. Main features of MESMIS case studies. Source: The authors based on the information from a sample of 25 case studies conducted in Latin America, Spain, Portugal, and USA

\begin{tabular}{|c|c|c|}
\hline Key aspects & $\begin{array}{l}\text { Description and number of cases } \\
(\mathrm{n}=25)\end{array}$ & Examples of the most representative of each category \\
\hline \multirow[t]{6}{*}{ NRM systems analyzed } & $\begin{array}{l}\text { Mixed (agroforestry, crops-livestock, crops- } \\
\text { livestock-forestry) - } 10\end{array}$ & $\begin{array}{l}\text { Modernized crop-livestock-forest system based on soil and water } \\
\text { conservation measures and diversification (local species and cultivars; } \\
\text { Gomes de Almeida and Biaconi 2007) }\end{array}$ \\
\hline & Cash crops -8 & Traditional Chinampas for the production of vegetables (Merlin 2009) \\
\hline & Basic crops -1 & Small-scale, multiple cropping systems (Moya et al. 2007) \\
\hline & Livestock - 4 & $\begin{array}{l}\text { Conventional vs. organic sheep production (Salcedo and García- } \\
\text { Trujillo 2005) }\end{array}$ \\
\hline & Forestry -1 & $\begin{array}{l}\text { Extraction vs. community managed forestry (Negreros-Castillo et al. } \\
\text { 2000) }\end{array}$ \\
\hline & Aquaculture - 1 & $\begin{array}{l}\text { Wetlands in monoculture vs. multiculture (Moctezuma-Malagón et al. } \\
\text { 2008) }\end{array}$ \\
\hline \multirow[t]{2}{*}{$\begin{array}{l}\text { Type of assessment } \\
\text { (longitudinal/cross-sectional) }\end{array}$} & $\begin{array}{l}\text { Simultaneous, contrasting systems (i.e., } \\
\text { reference vs. alternative) }-19\end{array}$ & $\begin{array}{l}\text { Conventional vs. alternative small-scale maize-dairy systems (Brunett- } \\
\text { Pérez et al. 2005) }\end{array}$ \\
\hline & $\begin{array}{l}\text { Longitudinal (same system before and after } \\
\text { management changes) }-6\end{array}$ & $\begin{array}{l}\text { Dairy sheep farm evaluated three times over } 10 \text { years of technological } \\
\text { change (North and Hewes 2006) }\end{array}$ \\
\hline \multirow[t]{4}{*}{ Leading institutional evaluator } & Academic - 11 & Dehesa (Mediterranean agroforestry system, Gaspar et al. 2009) \\
\hline & $\mathrm{NGO}-8$ & Small-scale lemon production (Orozco and Astier 2007) \\
\hline & Government/extension centre -3 & Conventional vs. organic cotton (Gomero and Velásquez 2007) \\
\hline & Farm/Farmers group - 3 & $\begin{array}{l}\text { Indigenous Coffee Cooperative Unión de Ejidos Majomut, Chiapas } \\
\text { (Pérez-Grovas 2000) }\end{array}$ \\
\hline \multirow[t]{3}{*}{$\begin{array}{l}\text { Spatial/organizative scale where } \\
\text { the evaluation is centered }\end{array}$} & Plot/ single farm -2 & $\begin{array}{l}\text { Conventional vs. diversified crop-livestock-forestry system in an } \\
\text { experimental farm (Gutiérrez-Cedillo et al. 2012) }\end{array}$ \\
\hline & Community - 18 & $\begin{array}{l}\text { Tequila production, } 27 \text { farms in one community (Bowen and Zapata } \\
\text { 2009) }\end{array}$ \\
\hline & Regional/farmers association -5 & $\begin{array}{l}\text { Organic coffee growers association, } 118 \text { farms in one region (Cárdenas- } \\
\text { Grajales et al. 2006) }\end{array}$ \\
\hline \multirow{4}{*}{$\begin{array}{l}\text { Time length of the alternative } \\
\text { system }\end{array}$} & Short term $(<3 \mathrm{yrs})-10$ & Vineyards in organic transition (Pino-Torres 2007) \\
\hline & Medium term (3-5 yrs) -3 & Conventional vs. organic coffee and agroforestry (Pérez-Grovas 2000) \\
\hline & Long term $(>5 \mathrm{yrs})-10$ & $\begin{array}{l}\text { Conventional vs. alternative irrigation system over } 20 \text { years (Ocampo- } \\
\text { Fletes 2004) }\end{array}$ \\
\hline & N/A -1 & No alternative system evaluated (Bowen and Zapata 2007) \\
\hline \multirow[t]{3}{*}{$\begin{array}{l}\text { Degree of participation from } \\
\text { farmers }\end{array}$} & Low -17 & $\begin{array}{l}\text { Farmers not involved in most steps of the evaluation process (Abbona et } \\
\text { al. 2007) }\end{array}$ \\
\hline & Medium - 1 & $\begin{array}{l}\text { Farmers involved in definition of general sustainability criteria (Pino- } \\
\text { Torres 2007) }\end{array}$ \\
\hline & High -7 & $\begin{array}{l}\text { Farmers involved in design, measurement, and integration of } \\
\text { sustainability indicators (Alemán et al. 2007) }\end{array}$ \\
\hline \multirow{2}{*}{$\begin{array}{l}\text { Indicators connected to } \\
\text { sustainability attributes as } \\
\text { defined by MESMIS }\end{array}$} & Yes -19 & $\begin{array}{l}\text { Use of all seven sustainability attributes defined by MESMIS (Aguirre } \\
\text { and Chiappe 2009) }\end{array}$ \\
\hline & No -6 & $\begin{array}{l}\text { Indicators derived from technological, economic, and social criteria } \\
\text { (Salcedo and García-Trujillo 2005) }\end{array}$ \\
\hline \multirow{2}{*}{$\begin{array}{l}\text { Integration of results using } \\
\text { multicriteria representation } \\
\text { techniques }\end{array}$} & AMOEBA/qualitative integration -24 & Use of AMOEBA graphs to present results (Duarte-Silveira 2005) \\
\hline & Modeling - 1 & $\begin{array}{l}\text { Linear programming used to define "ideal" system (Costa and Poeta } \\
\text { 2008) }\end{array}$ \\
\hline Multiple evaluation cycles & $\begin{array}{l}\text { No }-22 \\
\text { Yes }-3\end{array}$ & $\begin{array}{l}\text { Agrosilvopastoral alternative systems based on multicropping evaluated } \\
\text { after four years (Astier et al. 2007) }\end{array}$ \\
\hline \multirow[t]{4}{*}{ Main results } & Alternative system more sustainable -15 & $\begin{array}{l}\text { Improved yields and income, more stable production, increased } \\
\text { participation (Alemán et al. 2007) }\end{array}$ \\
\hline & Mixed results -3 & $\begin{array}{l}\text { Traditional system had higher cost-benefit ratio, similar income and } \\
\text { lower agrochemical use (Merlín 2009) }\end{array}$ \\
\hline & Reference system more sustainable -3 & $\begin{array}{l}\text { Increased labor efficiency, but reduced productivity (North and Hewes } \\
\text { 2006) }\end{array}$ \\
\hline & $\mathrm{N} / \mathrm{A}-4$ & No alternative system (Orozco and Astier 2007) \\
\hline
\end{tabular}


Fig. 2. A model of an agrosilvopastoral system generated in a case study in Chullpakasa, Bolivia. The first step of the assessment framework aims to understand and describe the natural resource management systems (NRMS) to be evaluated in systemic terms. Characterizing a NRMS implies describing its limits, subsystems, interactions, and its socio-environmental context. In this case we see a system composed of four subsystems tightly linked. Usually this type of information is generated in community workshops where stakeholders participate actively (Ortiz-Ávila 2008).

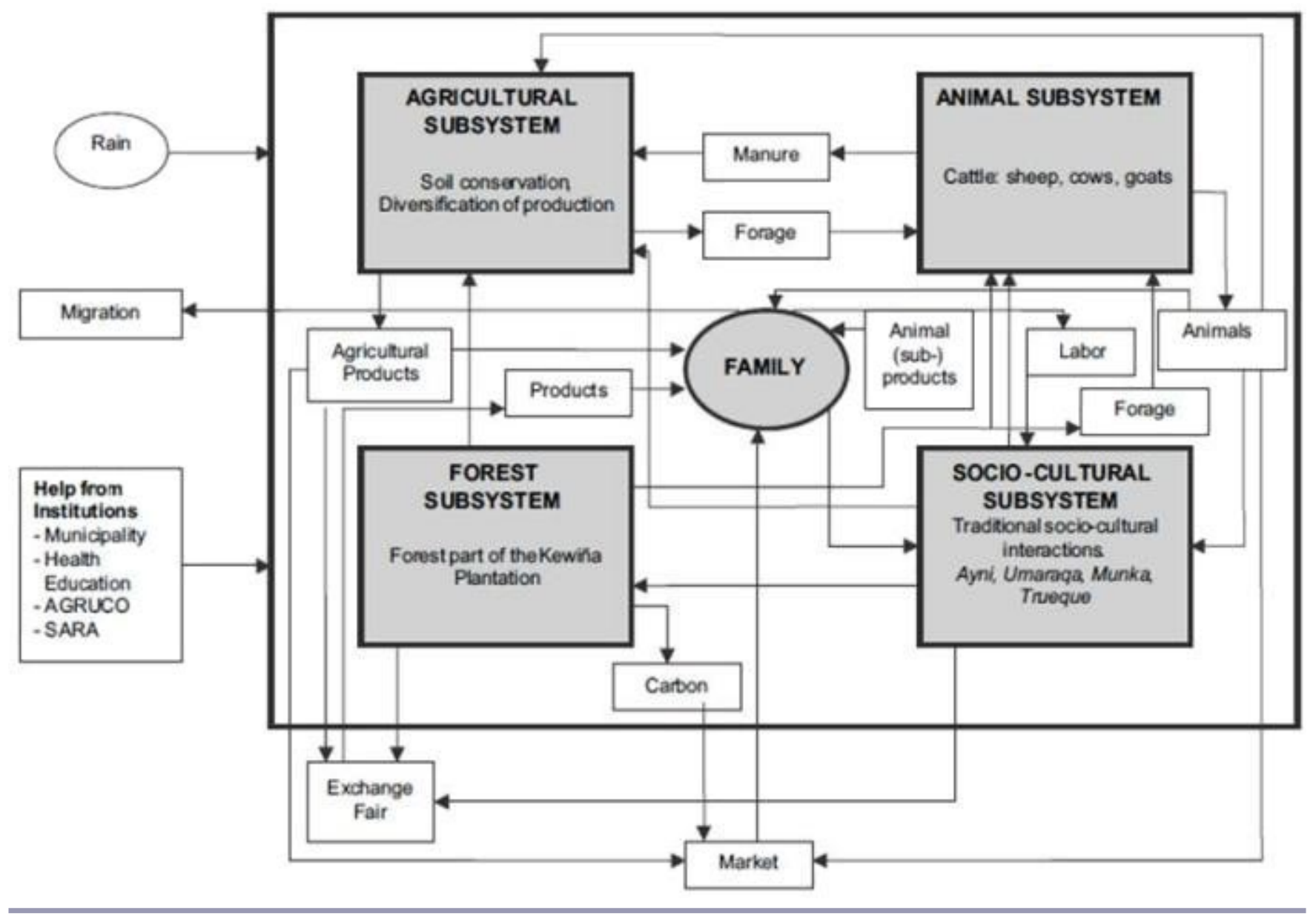

simulation models, embedded in fictitious but plausible socialecological narratives, were constructed. Step by step, the following five concepts are assimilated by the user: (1) the dynamic nature of sustainability attributes; (2) how natural resources respond in a complex and nonlinear manner to management strategies; (3) the adaptive-interactive character of sustainable natural resource management strategies; (4) trade-offs manifested among indicators when trying to optimize them simultaneously; and (5) stakeholder necessity for managing and solving conflicts that originated from their contrasting interests and views (García-Barrios and Pimm 2008).

A simulation model built to help people understand a complex system should simplify things as much as possible, but not to the point where the interesting characteristics of the phenomenon are lost (Gilbert 2005). We attempt to create models that provide a comprehensive overview of the range of possible long-term behaviors and of the main drivers, interactions, and thresholds involved (García-Barrios et al. $2008 a$ ). These programs also help the user to learn abstract concepts, first through a very experiential and interactive process, and later through a conceptual method. Two of these simulation models, SUSSI and LINDISSIMA (García-Barrios and Pimm 2008, García-Barrios et al. 2008b) were included in Interactive-MESMIS to facilitate the application of the operational structure (See Fig. 5; http://mesmis.gira.org.mx/ ) .

We have also developed AGRODIVERSITY, a very graphic and user-friendly agent-based model that challenges users to find the biological, ecological, and management parameters 
Fig. 3. Deriving indicators through the MESMIS framework. These are examples of common strengths/weakness and indicators registered in case studies. Sustainability attributes are translated into criteria that, at the same time, connect indicators with identified natural resource management systems (NRMS) strengths and weakness.

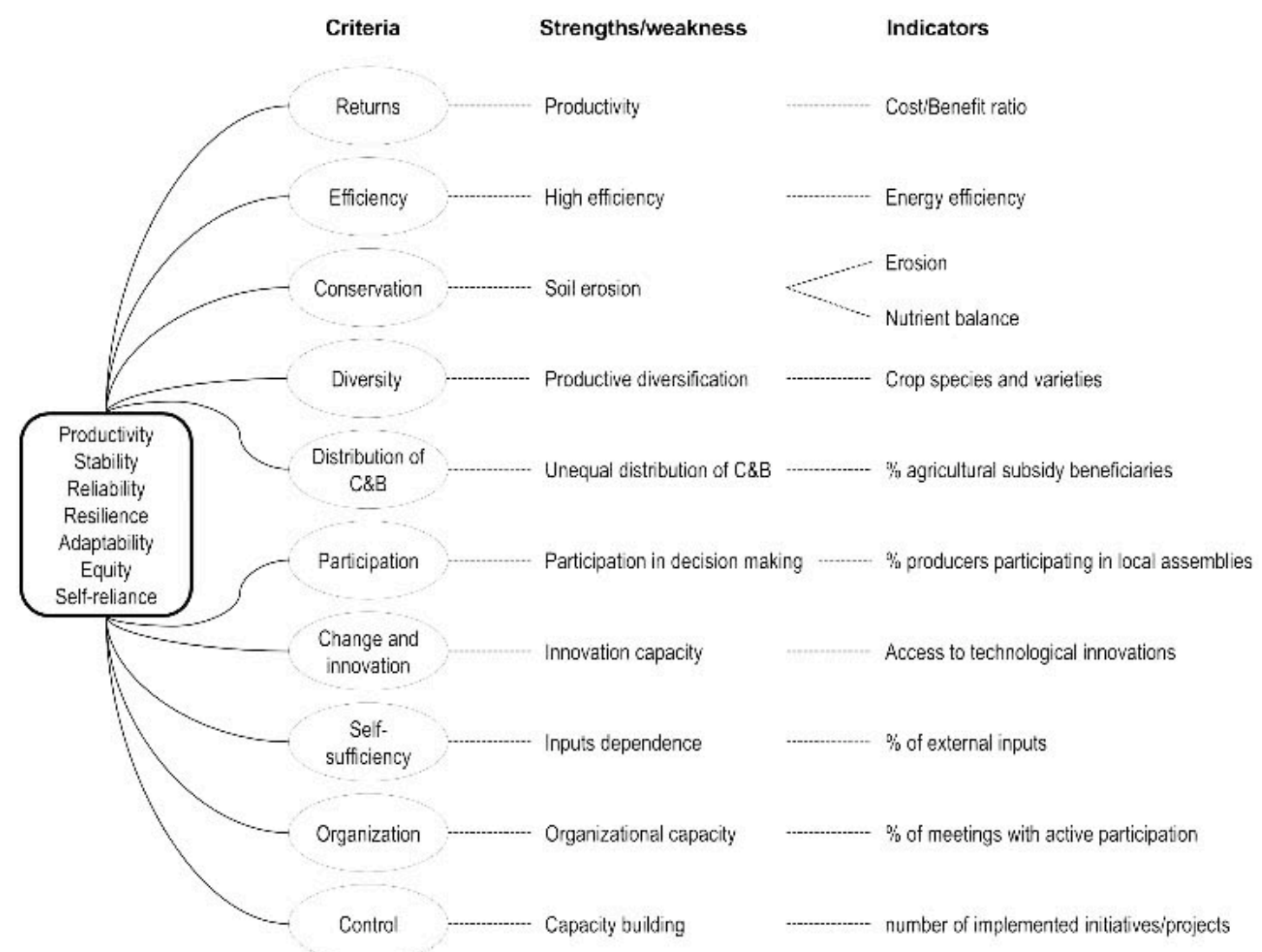

that allow a crop, weed, herbivore insect/natural enemy community to self-organize into a functionally biodiverse and economically sustainable agroecosystem (García-Barrios and Speelman 2006, Speelman and García-Barrios 2010).

These tools have been used in more than 20 local, national, and international training workshops addressed to graduate students, professionals, researchers, farmers' group leaders, and government officials. The favorable pedagogic results have been documented (García-Barrios et al. 2008b) even for people with little formal education (Speelman and GarcíaBarrios 2010). For those interested in understanding NRM modeling better or engaging in writing simple dynamical models, we have developed an illustrated introductory guide (García-Barrios et al. 2008a).

\section{Participatory processes: methods and tools}

The social process of NRM has become increasingly complex, interdependent, and uncertain (Gunderson and Holling 2002, Young et al. 2006). In consequence, the apparently independent actions of different stakeholders involved can produce unwanted and uncontrollable consequences for all (Bouwen and Taillieu 2004).

Reconciling rural well-being with sustainable land use and natural resource conservation in smallholder rural territories is a complex and challenging social task that requires the development of an adaptive comanagement process with the active participation of all stakeholders involved (Ostrom 2009, Poteete et al. 2010). This ultimately implies going beyond strategic cooperation and achieving substantive cooperation among social groups, which naturally benefits the most those that have been the least favored (García-Barrios and GarcíaBarrios 2008).

A whole new field of interest in developing social-ecological simulations and games for promoting participatory processes in rural settings is now evolving (Bousquet et al. 2002, Daré et al. 2008). Agent-based modeling has been proposed to be well suited for capturing the complex biophysical and socioeconomic settings and long-term behaviors found in peasant natural resource management systems in many 
developing countries (Berger et al. 2006, Speelman and García-Barrios 2010). The joint use of agent-based simulation and role-playing games, increasingly referred to as Companion Modeling (Collectif ComMod 2006), is relatively new (Barreteau et al. 2003), but flourishing. This strategy motivates stakeholders to become more involved, interact, and thereby reframe their views, strategies, interests, and conflicts. Role-playing games constitute a nonconfrontational social space in which human actions and their consequences can be explored and discussed by all stakeholders, including scientists (Barreteau 2003). The combination of simulation and role playing also generates a potentially powerful tool for interactive learning. Participants simultaneously acquire not only new eco-technical knowledge but also new social skills such as the ability to understand each other's views and interests, collectively explore scenarios, negotiate, define, and commit to practical solutions. Companion Modeling has proven its capacity to help stakeholders understand, mediate, and solve social conflicts involving common pool resources in rural settings (Bousquet and Trebuil 2005, Gurung et al. 2006, Daré et al. 2008).

Fig. 4. AMOEBA diagram showing progress toward sustainability on agrosilvopastoral systems throughout a nine-year period in Sinaloa, Mexico (created using Martínez 2005 and Perales et al. 2000). The diagram allows stakeholders to readily see to what extent the systems are improving in each of the selected indicators. Trade-offs, or synergies, and trends can thus be observed. For example, we can see that initial investment costs, yields, crop diversity improved, while cost-benefit ratio is decreasing a bit. Also participation in farmers' groups remains a challenge.

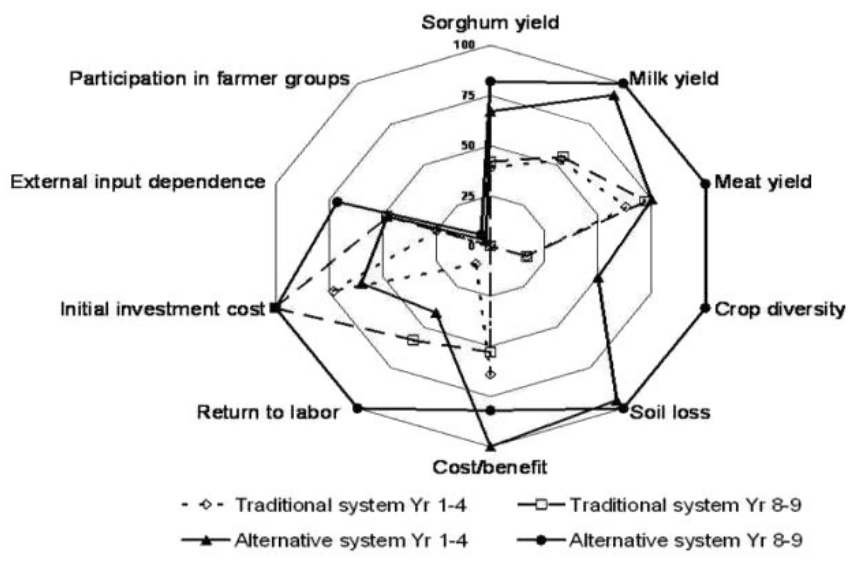

Within the context of the MESMIS, we have created a generic role game called "Sierra Springs" that can be adapted to a wider set of ecosystems and rural contexts (García-Barrios et al. 2009b). Through a dozen workshops (2009-2010), we have extended the educational use of Sierra Springs to other Man and the Biosphere Reserves and to academic settings in Latin America, Europe, USA, and South Africa. An online version of this board game is on trial, available at http://chiapasgames. org.

Our role-playing games are designed for two types of participants: (1) farmers, NGOs, government agencies, researchers, and other stakeholders that interact in a rural territory, normally a mountainous watershed, and (2) students and/or teachers. These games have been successfully played by students ranging from rural primary schools to $\mathrm{PhD}$ students at top universities in the USA.

Within this context, we are also currently developing a project in the buffer zone of an important Man and the Biosphere Reserve in Chiapas, Mexico, aimed at participatory design and implementation of sustainable silvopastoral production systems. This includes establishing experimental silvopastoral plots with many farmers, and an ongoing ComMod process. To date we have developed a thorough multiactor diagnosis that addresses the levels of consensus over different sustainability issues.

\section{BASIS FOR AN IMPROVED ITERATIVE EVALUATION CYCLE}

To include the most recent developments in each of the five components of the MESMIS Program, we propose an improved iterative evaluation, or assessment cycle to be tested and validated in a new set of case studies. This improved cycle is also needed to cope with the main challenges that emerged when applying the MESMIS approach in the different case studies: (1) a lack of quantitative and qualitative analysis of the system' dynamical behaviors, and the consequent difficulty to derive stability and resilience indicators, beyond resorting to strong assumptions and generalizations; (2) an insufficient consideration of trade-offs among attributes and among indicators, at a given scale and across scales; (3) the partial involvement of rural producers, and of other social actors who operate across scales, in the evaluation and decision making process; (4) the lack of longitudinal evaluations that could help understand and improve the transition or hybridization of the reference and alternative NRM system(s); and (5) the lack of scientific approaches and tools that could support local institutions conducting long-term participatory evaluation even without funding for long-term research.

We offer a general blueprint for building an improved iterative evaluation cycle that could better address the practical challenges of the MESMIS framework. We envision an evaluation cycle consisting of six main steps, three of them more linked to a diagnosis stage and three more related to a participatory planning stage that feed back on each other (Fig. 6 ). It should be noted that the proposed evaluation is longitudinal, i.e., the goal is to adaptively assess the sustainability of a particular NRMS through time, and to build 
Fig. 5. LINDISSIMA. The online educational tool "Production System Design and Negotiation Among Stakeholders in Conflict" in MESMIS-Interactive is a three-act drama in Spanish and English with 84 interactive screens that include narratives, detailed tutorials, simulations, quizzes, and multiactor agroforestry system design. Users work in groups and learn about sustainability attributes, nonlinear processes, multicriteria analysis, and conflict resolution.

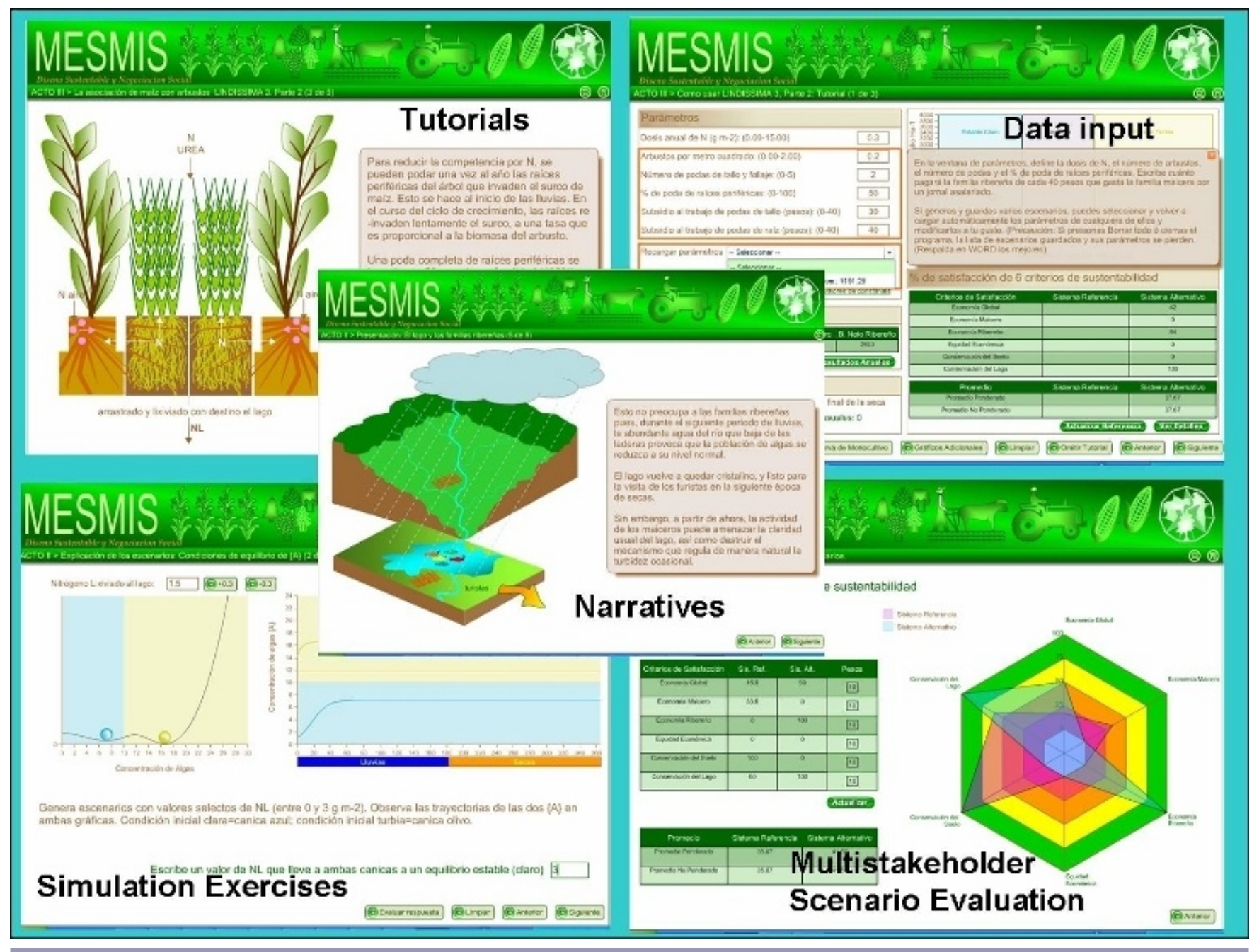

such assessment both with empirical time series of indicators, and with qualitative and quantitative stylized dynamical models of the systems' components, interactions, and actual/ potential behaviors. Throughout the different steps, pedagogic tools are applied to help participants understand concepts, particularly those regarding nonlinear, multidimensional processes; to collect and monitor information to assess the different indicators; to build dynamical models and roleplaying games representing the NRMS; and to integrate results with multicriteria methods to both collectively evaluate possible scenarios and to enable a cooperative approach to decision making. The evaluation cycle is therefore naturally linked with the teaching and training component of the MESMIS Program. Also, we hope that through the different participatory processes, the use of interactive learning tools, and by obtaining results tangible to local users, local institutions will be better able to internalize the sustainability assessment cycle and continue to carry it out on a long-term basis even without external funding.

Step 1 involves an intuitive analysis of the NRMS main components, interactions, drivers, and behavior(s). This analysis is built on the knowledge and experience of smallholders and other social actors involved in the process, including researchers. In this step, participants attempt to systematically describe the current status of the NRMS and its main challenges and opportunities in terms of sustainability. 
Fig. 6. The MESMIS Improved Iterative Evaluation Cycle encompasses a permanent process of participative diagnosis and planning, which includes six main steps closely related that feed back on each other.

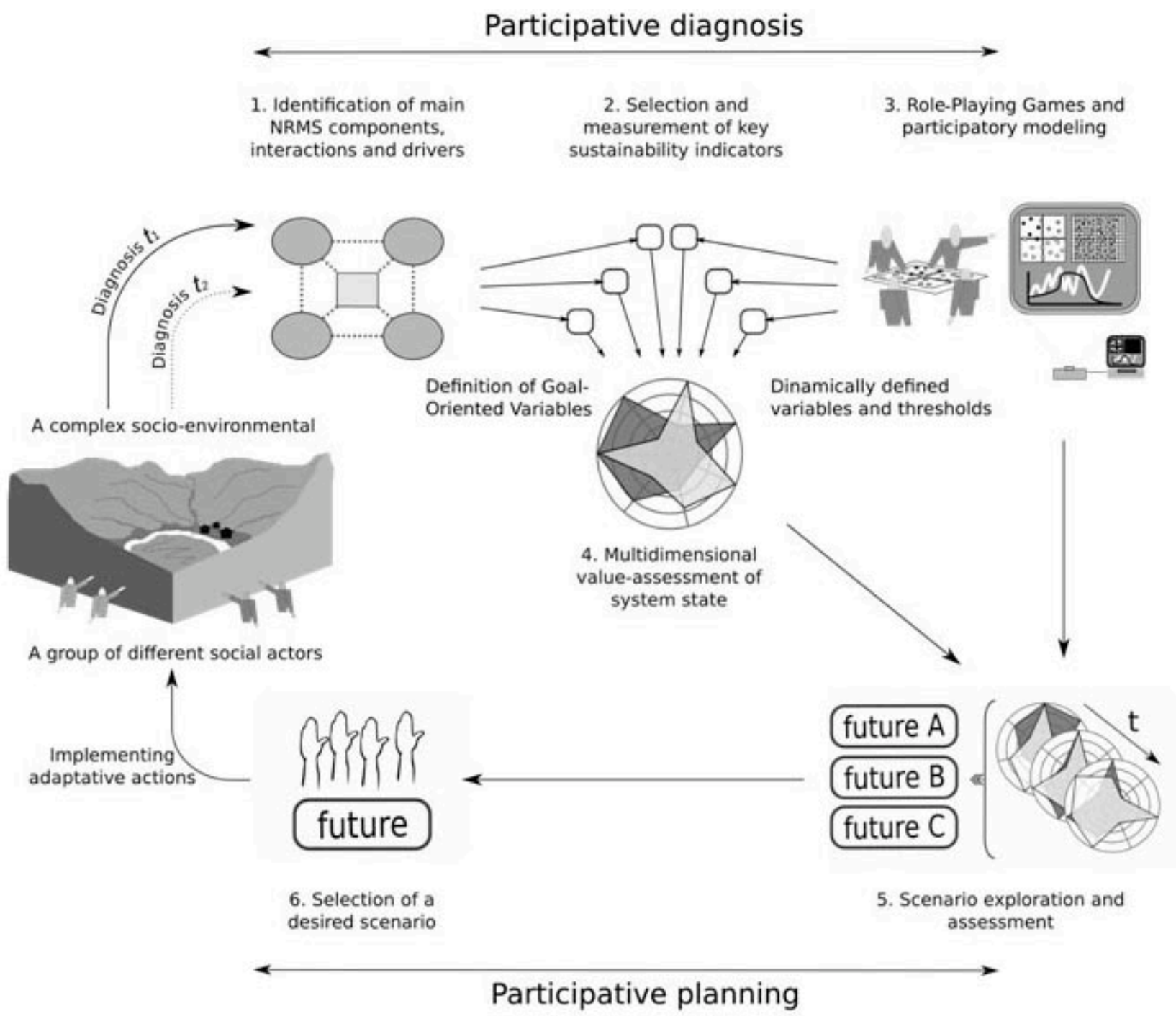

In Step 2, indicators are selected and defined in the following ways:

- The most relevant socio-environmental goals related to the NRMS under analysis are listed and their current and desired status is described quantitatively or qualitatively by the actors, e.g., through statements like "we produce one ton of maize per hectare and need to produce two tons"; "riparian vegetation and water quality are decreasing and we would like this to stop"; "local income inequity is high and we want it to be reduced"; "actors A and B compete for access to resources and would prefer to cooperate if possible".
- The most relevant current means and activities for achieving such goals are listed and characterized quantitatively/qualitatively, e.g., building on statements like "we apply industrial fertilizer to maize and wish to apply more as soil becomes impoverished"; "we have doubled the cattle stocking rate"; "former staple food producers have become middlemen for our marketable cattle".

- Goals and means are represented explicitly as indicators in a graphical conceptual model. Hypothetical cause and effect relations are proposed and explored to identify additional (hidden) critical variables, to integrate positive and negative feedback loops among variables, and to 
approximate quantitative/qualitative sustainability constraint and threshold values for the indicators representing goals and means.

As a result of the process, a manageable set of goal-oriented indicators is selected by participants seeking to capture the legitimate interests of all the stakeholders involved in the assessment, and the smallest possible list of drivers and interactions that define if such goals and means can be sustained is derived. This latter process is more elaborate because it requires that participants: (1) acquire an experiential understanding of the dynamical and systemic nature of sustainability attributes of NRMS; (2) build graphic representations of their conceptual models of the NRMS, including components, cause and effect relations, and feedback cycles; (3) "play out" the qualitative dynamics of critical indicators implicit in their diagrams, and discover the desirable and undesirable attractor(s) of the hypothetical system; and (4) confirm the relevance of the selected indicators. Deriving the minimal set of both types of indicators is key in reducing the costly and time consuming process of monitoring them. To facilitate conducting this step, a host of participatory processes for defining collective goals are available in the literature (e.g., Lynam et al. 2007). Also, highly intuitive and interactive didactic tools are becoming available to introduce academics and nonacademics to the basics of nonlinear dynamics, complexity science, and sustainability science. Dynamical system teaching resources (García-Barrios and Pimm 2008) and agent-based modeling tools have become more user-friendly, and have proved useful in the MESMIS teaching experience, for example, the LINDISSIMA and AGRODIVERSITY models. Conceptual modeling and user-friendly simulation software based on qualitative reasoning that can deal with qualitative and incomplete information about the components and interactions of NRMS is being developed (Bredeweg and Forbus 2003, Bredeweg et al. 2009), and the first study cases have been successful in modeling the restoration ecology of specific NRMS (Salles et al. 2006).

In Step 3, stakeholders integrate the selected goal-oriented indicators and sustainability-driver indicators into roleplaying games, in the form of board games and spatially explicit agent-based models. These games allow stakeholders to display their goals and strategies, discover the dynamical consequences of their management decisions, identify thresholds and trade-offs, and reveal the coordination and cooperation dilemmas involved in building a sustainable path for the NRMS under scrutiny (e.g., Janssen et al. 2010, García Barrios et al. 2011). In the process, the indicators listed in step 2 , and the model as a whole, are reconsidered and refined. Different strategies for participatory modeling have been developed and explored in the past two decades with success (Etienne 2011). Of course, the modeling tools and resources described in step 2 should also be used here.
Step 4 involves the integrated assessment of indicators, using multicriteria representation tools and techniques, with continuous feedback from steps 2 and 3. For each indicator the state of the system is judged according to a "scale of preferences" in terms of sustainability, where optimal values, targets, or critical thresholds are used to define the most preferred state. Multicriteria representation tools such as the AMOEBA diagram are commonly used at this stage.

In Step 5 a scenario exploration and assessment, which involves a prospective analysis and social negotiation of potential courses of action available for decision makers, is undertaken and, therefore, trade-offs among attributes and indicators can be visualized and analyzed. The final step (6) is the selection of a desired scenario that is translated into a set of adaptive/corrective actions oriented to improve the sustainability of the NRMS under analysis. This process, in turn, triggers a new diagnosis-planning cycle that begins at time "t2" (Fig. 6). The Companion Modeling (COMMOD) framework (Etienne 2011) and tools are well suited for aiding in steps 3 to 6 . We have started to conduct and test this improved MESMIS evaluation cycle in the buffer zone of a Man and the Biosphere Reserve in Chiapas, Mexico with encouraging results (Cruz-Morales et al. 2011, Brunel-Manse and García-Barrios 2012).

\section{CONCLUSION}

The concept, the goals, and the strategies for achieving SES sustainability are rapidly evolving in the midst of intense and sometimes contentious debate. There is no single theory that suffices for this challenge; approaches so far need to be fundamentally eclectic and integrate recent developments from measurement-oriented approaches to sustainability assessment, theory of complex system dynamics, participatory processes, agent-based simulation, and role-playing games. In particular, within small-scale farm territories, natural resource management is inextricably related to the livelihoods of millions of smallholders in Latin America and the world at large, and continues to be central in the analysis of sustainable and unsustainable strategies and resultant SES scenarios.

Although the theoretical discussion about sustainability is booming, funding for long-term research programs in Latin America and for many other regions is still a major challenge. The MESMIS Program has actually survived by surfing through and bridging a large set of short-term projects. Assessment and monitoring are seen by funders and organizations more as the end-point of a project rather than a continuous activity. Priorities are also on short-term impacts rather than on sustaining longer term strategies. In fact, several institutions explicitly preclude the funding for more than two to three years, which completely contradicts sustainability objectives. Finally, the assessment itself and the development of learning and methodological tools are often a low funding priority. These limitations should be urgently overcome. 
Sustainability assessments need to support bottom-up, adaptive comanagement strategies; therefore, characterizing the local contextual circumstances that are most relevant for sustainability in a given place is essential. Unfortunately, the topic is still foreign not only to farmers but to many researchers, students, NGOs, policy makers/operators, and other interested groups. The MESMIS program has attempted to bridge theory, empirical studies, and social action to enable small-scale farmers and other relevant stakeholders to continuously assess the dynamic social-ecological consequences of NRM decisions made in these territories. So far the experience has been rewarding, as the interest for the different methods and tools developed within MESMIS continue to grow, and more case studies are conducted aimed at finding more sustainable alternatives for small-scale NRMS. Because the MESMIS Program is itself an adaptive process, we have proposed in this paper an improved operative framework with emphasis on the dynamics/participatory aspects of sustainability assessments.

Putting in practice this new form of sustainability assessments requires a sustained, long-term, multi- and interdisciplinary effort. To be effective this effort needs to encompass a range of scenarios from the incorporation of sustainability science programs into formal curricula in universities, to training courses in rural settings. Finally but not least important, it should be noted that these types of efforts will be more successful in those circumstances and settings where adaptive, participative governance of social-environmental processes is already making significant progress.

Responses to this article can be read online at: http://www.ecologyandsociety.org/voll7/iss3/art25/ responses/

\section{Acknowledgments:}

We thank three anonymous reviewers for their very useful comments. This study is part of the larger MESMIS project, financed by CONACYT Project 51293, and FORDECYT Project 116306, Mexico. The authors express their gratitude to all farmers and researchers that used the MESMIS framework, and who shared their documents and experiences with us.

\section{LITERATURE CITED}

Abbona, E. A., S. J. Sarandón, M. E. Marasas, and M. Astier. 2007. Ecological sustainability evaluation of traditional management in different vineyard systems in Berisso, Argentina. Agriculture, Ecosystems \& Environment 119:335-345. http://dx.doi.org/10.1016/j.agee.2006.08.001
Aguirre, O., and M. Chiappe. 2009 Evaluación de Estrategias Sustentables en Sistemas de Producción Hortícolas del Áea de Influencia de Salto (Uruguay). Revista Brasileira de Agroecologia 4(2):454-457

Alemán, S. T., T. J. Nahed, and M. J. López. 2007. Evaluación de la sustentabilidad de dos sistemas de producción ovina en comunidades tzotziles. Pages 11-55 in M. Astier and J. Hollands, editors. Sustentabilidad y campesinado. Seis experiencias agroecológicas en Latinoamérica. MundiPrensa, Grupo Interdisciplinario de Tecnología Rural Apropiada (GIRA A.C.), Centre for Learning on Sustainable Agriculture (ILEIA), and Inter-church Organisation for Development Cooperation (ICCO), Mexico City, Mexico.

Astier, M., and C. González. 2008. Formulación de indicadores socio-ambientales para evaluaciones de sistemas de manejo complejos. Pages 73-94 in M. Astier, Y. GalvánMiyoshi, and O. R. Masera, editors. Evaluación de sustentabilidad. Un enfoque dinámico y multidimensional. Sociedad Española de Agricultura Ecológica (SEAE), Centro de Investigaciones en Geografía Ambiental (CIGA), Centro de Investigaciones en Ecosistemas (CIEco-UNAM), Grupo Interdisciplinario de Tecnología Rural Apropiada (GIRA A. C.), Fundación Instituto de Agricultura Ecológica y Sustentable, and MundiPrensa, Catarroja, Valencia, Spain.

Astier, M., and J. Hollands. 2007. Sustentabilidad y campesinado. Seis experiencias agroecológicas en Latinoamérica. Second edition. MundiPrensa, Grupo Interdisciplinario de Tecnología Rural Apropiada (GIRA A.C.), Centre for Learning on Sustainable Agriculture (ILEIA), and Interchurch Organisation for Development Cooperation (ICCO), Mexico City, Mexico.

Astier, M., E. Pérez, T. Ortiz-vila, and F. Mota. 2007. Sustentabilidad de sistemas campesinos de maíz después de cuatro años: el segundo ciclo de evaluación MESMIS. Pages 85-120 in M. Astier and J. Hollands, editors. Sustentabilidad $y$ campesinado. Seis experiencias agroecológicas en Latinoamérica. MundiPrensa, Grupo Interdisciplinario de Tecnología Rural Apropiada (GIRA A.C.), Centre for Learning on Sustainable Agriculture (ILEIA), and Interchurch Organisation for Development Cooperation (ICCO), Mexico City, Mexico.

Astier, M., E. N. Speelman, S. López-Ridaura, O. R. Masera, and C. E. González-Esquivel. 2011. Sustainability indicators, alternative strategies and trade-offs in peasant agroecosystems: analysing 15 case studies from Latin America. International Journal of Agricultural Sustainability 9(3):409-422. http://dx. doi.org/10.1080/14735903.2011.583481

Barreteau, O. 2003. The joint use of role-playing games and models regarding negotiation processes: characterization of 
associations. Journal of Artificial Societies and Social Simulation 6(2). [online] URL: http://jasss.soc.surrey.ac.uk/6/2/3. $\underline{\mathrm{html}}$

Barreteau, O., C. Le Page, and P. D'Aquino. 2003. Roleplaying games, models and negotiation processes. Journal of Artificial Societies and Social Simulation 6(2). [online] URL http://jasss.soc.surrey.ac.uk/6/2/10.html

Berkes, F., J. Colding, and C. Folke. 2002. Navigating socialecological systems: building resilience for complexity and change. First Edition. Cambridge University Press, Cambridge, UK. http://dx.doi.org/10.1017/CBO9780511541957

Berger, T., P. Schreinemachers, and J. Woelcke. 2006. Multiagent simulation for the targeting of development policies in less-favored areas. Agricultural Systems 88:28-43. http://dx.d oi.org/10.1016/j.agsy.2005.06.002

Boege, E. 2009. El patrimonio biocultural de los pueblos indígenas de México. Instituto Nacional de Antropología e Historia (INAH), Consejo Nacional para la Cultura y las Artes (CONACULTA), and Comisión Nacional de los Derechos Humanos (CNDH), Mexico City, Mexico.

Bousquet, F., O. Barreteau, P. D'Aquino, M. Etienne, S. Boisseau, S. Aubert, C. Le Page, D. Babin, and J. C. Castella. 2002. Multi-agent systems and role games: collective learning processes for ecosystem management. Pages 248-285 in M. Janssen, editor. Complexity and ecosystem management: the theory and practice of multi-agent approaches. Edward Elgar, Cheltenham, UK.

Bousquet, F., and G. Trebuil, editors. 2005. Introduction to companion modelling and multi-agent systems for integrated natural resource management in Asia. International Rice Research Institute, Los Baños, Phillipines.

Bouwen, R., and T. Taillieu. 2004. Multi-party collaboration as social learning for interdependence: developing relational knowing for sustainable natural resource management. Journal of Community \& Applied Social Psychology 14:137-153. http://dx.doi.org/10.1002/casp.777

Bowen, S., and A. V. Zapata. 2009. Geographical indications, terroir, and socioeconomic and ecological sustainability: the case of tequila. Journal of Rural Studies 25(1):108-119. http: //dx.doi.org/10.1016/j.jrurstud.2008.07.003

Bredeweg, B., and K. Forbus. 2003. Qualitative modeling in education. AI Magazine 24(4):35-46.

Bredeweg, B., F. Linnebank, A. Bouwer, and J. Liem. 2009. Garp3-Workbench for qualitative modelling and simulation. Ecological Informatics 4(5-6):263-281. http://dx.doi.org/10.1 016/j.ecoinf.2009.09.009
Brunel-Manse, C., and L. García-Barrios. 2012 Acknowledging consensus and dissent among and within stakeholder groups over conservation, production and urbanization in a Mexican "Man \& the Biosphere" Reserve. Research Journal of Biological Sciences 6(9):459-467.

Brunett-Pérez, L., C. González-Esquivel, and L. A. GarcíaHernández. 2005. Evaluación de la sustentabilidad de dos agroecosistemas campesinos de producción de maíz y leche, utilizando indicadores. Livestock Research for Rural Development 17(7):78. [online] URL: http://www.lrrd.org/lrr d17/7/pere17078.htm

Brussaard, L., P. Caron, B. Campbell, L. Lippert, S. Mainka, R. Rabbinge, D. Babin, and M. Pulleman. 2010. Reconciling biodiversity conservation and food security: scientific challenges for a new agriculture. Current Opinion in Environmental Sustainability 2:34-42. http://dx.doi.org/10.1016/ j.cosust.2010.03.007

Capra, F. 2002. The hidden connections: a science of sustainable living. Anchor Books, New York, New York, USA.

Cárdenas-Grajales, G. I., H. Giraldo-Gómez, A. IdárragaQuintero, L. N. Vásquez-Grisales, and Asociación de Caficultores Orgánicos de Colombia (ACOC). 2006. Desarrollo y validación de metodología para evaluar con indicadores la sustentabilidad de sistemas productivos campesinos de la Asociación de Caficultores Orgánicos de Colombia - ACOC. Investigaciones de Unisarc 4:22-46.

Clayton, A. M. H., and N. J. Radcliffe. 1996. Sustainability: a systems approach. Island Press, New York, New York, USA.

Collectif ComMod. 2006. Modélisation d'accompagnement. Pages 217-228 in F. Amblard and D. Phan, editors. Modélisation et simulation multi-agents: applications aux sciences de l'homme et de la société. Hermès Sciences, London, UK.

Conway, G. R. 1994. Sustainability in agricultural development: trade-offs between productivity, stability, and equitability. Journal for Farming Systems Research and Extension 4(2):1-14.

Costa, M., and A. Poeta. 2008. Stages for the more sustainable farm. 12th Congress of the European Association of Agricultural Economists. EAAE, Ghent, Belgium.

Cruz-Morales, J., R. Trujillo-Vázquez, L. E. García-Barrios, J. M. Ruiz-Rodríguez, and J. A. Jiménez-Trujillo. 2011. Buenas Prácticas para la Ganadería Sustentable en la Reserva de la Biosfera La Sepultura (REBISE). Universidad Autónoma Chapingo, El Colegio de la Frontera Sur, Conservación Internacional-México y Comisión de Áeas 
Naturales Protegidas, San Cristobal de las Casas, Chiapas, Mexico.

Daré, W., R. Ducrot, A. Botta, and M. Etienne. 2008. Repères méthodologiques pour la mise en oeuvre d'une démarche de modélisation d'accompagnement. Cardère éditions, Laudun, France.

Duarte-Silveira, N. 2005. Sostenibilidad socioeconómica y ecológica de sistemas agroforestales de café (Coffea arabica) en la microcuenca del Río Sensemiles, Copán, Honduras. Thesis. Tropical Agricultural Research and Higher Education Center (CATIE), Cartago, Turrialba, Costa Rica.

Economic Comission for Latin America and the Caribbean (ECLAC). 2009. The outlook for agriculture and rural development in the Americas: a perspective on Latin America and the Caribbean. ECLAC, Inter-American Institute for Cooperation on Agriculture, Food and Agriculture Organization, Santiago, Chile.

Étienne, M. 2011. Companion modelling: a participatory approach to support sustainable development. Update Sciences \& Technologies collection. Editions Quae, Versailles, France.

Gallopín, G. C. 1997. Indicators and their use: information for decision-making. Part one-introduction. Pages 13-27 in B. Moldan and S. Bilharz, editors. Sustainability indicators. A report on the project on indicators of sustainable development. Wiley, Chichester, UK.

Galván-Miyoshi, Y. 2008. Integración de indicadores en la evaluación de sustentabilidad: de los índices agregados a la representación multicriterio. Pages 95-119 in M. Astier, Y. Galván-Miyoshi, and O. Masera, editors. Evaluación de sustentabilidad. Un enfoque dinámico y multidimensional. Sociedad Española de Agricultura Ecológica (SEAE), Centro de Investigaciones en Geografía Ambiental (CIGA), Centro de Investigaciones en Ecosistemas (CIEco-UNAM), Grupo Interdisciplinario de Tecnología Rural Apropiada (GIRA A. C.), Fundación Instituto de Agricultura Ecológica y Sustentable, and MundiPrensa, Catarroja, Valencia, Spain.

García, R. 1994. Interdisciplinariedad y sistemas complejos. Pages 85-123 in E. Leff, editor. Ciencias sociales y formación ambiental, Gedisa, Barcelona, Spain.

García-Barrios, L., Y. Galván-Miyoshi, I. A. ValdiviesoPérez, O. Masera, G. Bocco, and J. Vandermeer. 2009a. Neotropical forest conservation, agricultural intensification, and rural out-migration: the Mexican experience. BioScience 59:863-87.

García-Barrios, L., and R. García-Barrios. 1992. La modernización de la pobreza. Dinámica del cambio técnico entre los campesinos temporaleros de México. Revista Estudios Sociológicos 10:263-288.
Garcia-Barrios, L., R. García-Barrios, A. Waterman, and J. Cruz-Morales. 2011. Social dilemmas and individual/group coordination strategies in a complex rural land-use game. International Journal of the Commons 5:(2)364-387.

García-Barrios, L., O. Masera, and R. García-Barrios. 2008a. Construcción y uso de modelos dinámicos sencillos para evaluar estrategias de manejo productivo de recursos bióticos. Una guía básica ilustrada. Pages 109-128 in M. Astier, Y. Galván-Miyoshi, and O. Masera, editors. Evaluación de sustentabilidad. Un enfoque dinámico y multidimensional. Sociedad Española de Agricultura Ecológica (SEAE), Centro de Investigaciones en Geografía Ambiental (CIGA), Centro de Investigaciones en Ecosistemas (CIEco-UNAM), Grupo Interdisciplinario de Tecnología Rural Apropiada (GIRA A. C.), Fundación Instituto de Agricultura Ecológica y Sustentable, and MundiPrensa, Catarroja, Valencia, Spain.

García-Barrios, L., and M. Pimm. 2008. Simuladores de escenarios complejos socioambientales: herramientas de apoyo para entender, evaluar y negociar estrategias sustentables de manejo de recursos naturales. Pages 169-172 in M. Astier, Y. Galván-Miyoshi, and O. Masera, editors. Evaluación de sustentabilidad. Un enfoque dinámico y multidimensional. Sociedad Española de Agricultura Ecológica (SEAE), Centro de Investigaciones en Geografía Ambiental (CIGA), Centro de Investigaciones en Ecosistemas (CIEco-UNAM), Grupo Interdisciplinario de Tecnología Rural Apropiada (GIRA A.C.), Fundación Instituto de Agricultura Ecológica y Sustentable, and MundiPrensa, Catarroja, Valencia, Spain.

García-Barrios, L. E., and E. N. Speelman. 2006. AGRODIVERSITY ver.2, CD-ROM. El Colegio de la Frontera Sur, San Cristobal de las Casas, Chiapas, Mexico.

García-Barrios, L., E. N. Speelman, and M. Pimm. 2008b. An educational simulation tool for negotiating sustainable natural resource management strategies among stakeholders with conflicting interests. Ecological Modelling 210:215-226

García-Barrios, L., A. Waterman, R. García-Barrios, C. Brunel-Manse, and J. Cruz-Morales. 2009b. Sierra Springs: a generic role-playing game addressing conflict and cooperation in land, forest and water management in a tropical mountain watershed. In Proceedings of the 40th International Simulation and Gaming Conference, 29 June 3-July, Singapore, Singapore.

García-Barrios, R., and L. García-Barrios. 2008. La sociedad controlable y la sustentabilidad. Pages 109-128 in M. Astier, Y. Galván-Miyoshi, and O. Masera, editors. Evaluación de sustentabilidad. Un enfoque dinámico y multidimensional. Sociedad Española de Agricultura Ecológica (SEAE), Centro de Investigaciones en Geografía Ambiental (CIGA), Centro de Investigaciones en Ecosistemas (CIEco-UNAM), Grupo Interdisciplinario de Tecnología Rural Apropiada (GIRA A. 
C.), Fundación Instituto de Agricultura Ecológica y Sustentable, and MundiPrensa, Catarroja, Valencia, Spain.

Gaspar, P., F. J. Mesías, M. Escribano, and F. Pulido. 2009. Sustainability in Spanish extensive farms (Dehesas): an economic and management indicator-based evaluation. Rangeland Ecology \& Management 62:153-162. http://dx.doi. org/10.2111/07-135.1

Gilbert, N. 2005. Agent-based social simulation: dealing with complexity. Centre for Research on Social Simulation, University of Surrey, Guildford, UK. [online] URL: http://cre ss.soc.surrey.ac.uk/web/resources/ABSS\%20-\%20dealing $\% 20$ with\% 20complexity-1-1.pdf

Gomero, O. L., and A. H. Velásquez. 2007. Evaluación de la sustentabilidad del sistema de algodón orgánico en la zona de trópico húmedo del Perú San Martín, Tarapoto. Pages 57-73 in M. Astier and J. Hollands, editors. 2007. Sustentabilidad y campesinado. Seis experiencias agroecológicas en Latinoamérica. Second Edition. MundiPrensa, Grupo Interdisciplinario de Tecnología Rural Apropiada (GIRA A.C.), Centre for Learning on Sustainable Agriculture (ILEIA), and Interchurch Organisation for Development Cooperation (ICCO), Mexico City, Mexico.

Gomes de Almeida, S., and F. G. Bianconi. 2007. Sustentabilidad Económica de un Sistema Familiar en una Región Semiarida de Brasil. Pages 121-156 in M. Astier and J. Hollands, editors. 2007. Sustentabilidad y campesinado. Seis experiencias agroecológicas en Latinoamérica. Second Edition. MundiPrensa, Grupo Interdisciplinario de Tecnología Rural Apropiada (GIRA A.C.), Centre for Learning on Sustainable Agriculture (ILEIA), and Inter-church Organisation for Development Cooperation (ICCO), Mexico City, Mexico.

Grau, H. R., and M. Aide. 2008. Globalization and land-use transitions in Latin America. Ecology and Society 13(2): 16. [online] URL: http://www.ecologyandsociety.org/vol13/iss $2 /$ art16/

Gunderson, L. H., and C. S. Holling. 2002. Panarchy: understanding transformations in human and natural systems. Island Press, Washington, D.C., USA.

Gurung, T. R., F. Bousquet, and G. Trébuil. 2006. Companion modeling, conflict resolution, and institution building: sharing irrigation water in the Lingmuteychu watershed, Bhutan. Ecology and Society 11(2): 36. [online] URL: http://www.eco logyandsociety.org/vol11/iss2/art36/

Gutiérrez-Cedillo, J. G., L. A. Aguilera-Gómez, C. E. González-Esquivel, and J. I. Juan-Pérez. 2012. Evaluación de la sustentabilidad posterior a una intervención agroecológica en el subtrópico del Altiplano Central de México. Tropical and Subtropical Agroecosystems 15:15-24.

Holling, C. S. 2001. Understanding the complexity of economic, ecological, and social systems. Ecosystems 4:390-405. http://dx.doi.org/10.1007/s10021-001-0101-5
Holling, C. S., and L. H. Gunderson. 2002. Resilience and adaptive cycles. Pages 25-62 in L. H. Gunderson and C. S. Holling, editors. Panarchy: understanding transformations in human and natural systems. Island Press, Washington, D.C., USA.

Jackson, L., M. van Noordwijk, J. Bengtsson, W. Foster, L. Lipper, M. Pulleman, M. Said, J. Snaddon, and R. Vodouhe. 2010. Biodiversity and agricultural sustainagility: from assessment to adaptive management. Current Opinion in Environmental Sustainability 2:80-87. http://dx.doi.org/10.1016/ j.cosust.2010.02.007

Janssen, M. A., R. Holahan, A. Lee, and E. Ostrom. 2010. Lab experiments for the study of social-ecological systems. Science 328:613-617. http://dx.doi.org/10.1126/science.1183532

Keating, B. A., P. S. Carberry, G. L. Hammer, M. E. Probert, M. J. Robertson, D. Holzworth, N. I. Huth, J. N. G. Hargreaves, H. Meinke, Z. Hochman, G. McLean, K. Verburg, V. Snow, J. P. Dimes, M. Silburn, E. Wang, S. Brown, K. L. Bristow, S. Asseng, S. Chapman, R. L. McCown, D. M. Freebairn, and C. J. Smith. 2003. An overview of APSIM, a model designed for farming systems simulation. European Journal of Agronomy 18:267-288. http://dx.doi.org/10.1016/S1161-0301 (02)00108-9

López-Ridaura, S. 2005. Multi-scale sustainability evaluation: a frameworkfor the derivation and quantification of indicators for natural resource management systems. Dissertation. Wageningen University and Reseah Center, Wageningen, The Netherlands.

López-Ridaura, S., O. Masera, and M. Astier. 2002. Evaluating the sustainability of complex socio-environmental systems. The MESMIS framework. Ecological Indicators 2:135-148. http://dx.doi.org/10.1016/S1470-160X(02)00043-2

López-Ridaura, S., M. K. van Ittersum, O. R. Masera, P. A. Leffelaar, M. Astier, and H. van Keulen. 2005. Sustainability evaluation. Applying ecological principles and tools to natural resource management systems. Pages 139-167 in A. D. Maples, editor. Sustainable development: new research. NovaScience, Hauppauge, New York, USA.

Lynam, T., W. De Jong, D. Sheil, T. Kusumanto, and K. Evans. 2007. A review of tools for incorporating community knowledge, preferences, and values into decision making in natural resources management. Ecology and Society 12(1): 5. [online] URL: http://www.ecologyandsociety.org/vol12/iss1/ $\underline{\operatorname{art} 5 /}$

Manuel-Navarrete, D., S. Slocombe, and B. Mitchell. 2006. Science for place-based socioecological management: lessons from the Maya forest (Chiapas and Petén). Ecology and Society 11(1): 8. [online] URL: http://www.ecologyandsociety. org/vol11/iss $1 /$ art8/ 
Martínez, C. O. 2005. Evaluación de la sostenibilidad de un modelo de sistema agrosilvopastoril alternativo y su factibilidad de implementarse por productores del sur de Sinaloa. Thesis. Universidad Autónoma Chapingo, Texcoco, Estado de Mexico, Mexico.

Masera, O. R., M. Astier, and S. López. 1999. Sustentabilidad y manejo de recursos naturales: El Marco de evaluación MESMIS. MundiPrensa-GIRA-UNAM, Mexico City, Mexico.

Masera, O., and S. López-Ridaura, editors. 2000. Sustentabilidad y sistemas campesinos: cinco experiencias de evaluación en el México rural. MundiPrensa, Grupo Interdisciplinario de Tecnología Rural Apropiada (GIRA A. C.), Programa de las Naciones Unidas para el Medio Ambiente (PNUMA), and Instituto de Ecología (IE-UNAM), Mexico City, Mexico.

Mayer, A. L. 2008. Strengths and weaknesses of common sustainability indices for multidimensional systems. Environment International 34:277-291. http://dx.doi.org/10.1 016/j.envint.2007.09.004

Merlín, Y. 2009. Evaluación de dos sistemas de manejo de recursos naturales de Xochimilco con indicadores de sustentabilidad. Thesis. Instituto de Ecología A.C., Xalapa, Veracruz, Mexico.

Mitchell, G., A. May, and A. McDonald. 1995. PICABUE: a methodological framework for the development of indicators of sustainable development. International Journal of Sustainable Development \& World Ecology 2:104-123. http:// dx.doi.org/10.1080/13504509509469893

Moctezuma-Malagón, A., C. González-Esquivel, G. De la Lanza-Espino, and C. González-Rebeles Islas. 2008. A methodology for evaluating the sustainability of inland wetland systems. Aquaculture International 16:525-537. http ://dx.doi.org/10.1007/s10499-007-9163-5

Moya, G., X. Caamal, A. Ku Ku, A. B. Chan Xool, I. Armendáriz, I. Flores, J. Moguel, M. Noh Poot, M. Rosales, and X. J. Domínguez. 2007. La sustentabilidad que viene de lejos: una evaluación multidisciplinaria e intercultural campesina de los mayas en Xohuayan, Yucatán. Pages 161-201 in M. Astier and J. Hollands, editors. 2007. Sustentabilidad y campesinado. Seis experiencias agroecológicas en Latinoamérica. Second Edition. MundiPrensa, Grupo Interdisciplinario de Tecnología Rural Apropiada (GIRA A. C.), Centre for Learning on Sustainable Agriculture (ILEIA), and Inter-church Organisation for Development Cooperation (ICCO), Mexico City, Mexico.

Negreros-Castillo, P., J. C. Núñez, and L. Merino. 2000. Evaluación de la sustentabilidad del sistema de manejo forestal de la Organización de Ejidos Productores Forestales de la Zona
Maya de Quintana Roo. Pages 83-141 in O. Masera and S. López-Ridaura, editors. 2000. Sustentabilidad y sistemas campesinos: cinco experiencias de evaluación en el México rural. MundiPrensa, Grupo Interdisciplinario de Tecnología Rural Apropiada (GIRA A.C.), Programa de las Naciones Unidas para el Medio Ambiente (PNUMA), and Instituto de Ecología (IE-UNAM), Mexico City, Mexico.

North, K., and D. Hewes. 2006. Seguimiento de fincas para el progreso hacia la sostenibilidad. LEISA Revista de Agroecología 22(1):33-36.

Ocampo-Fletes, I. 2004. Gestión del agua y sustentabilidad de los sistemas de pequeño riego. El caso del canal San Félix, Atlixco, Mexico. Dissertation. University of Córdoba, Córdoba, Spain.

Orozco, Q., and M. Astier. 2007. Evaluación de sustentabilidad del Proyecto: Renovación de Plantaciones del Limón Mexicano y Tecnificación del Riego para el uso eficiente del agua. Primer ciclo de evaluación utilizando el marco MESMIS. Technical Report. Grupo Interdisciplinario de Tecnología Rural Apropiada (GIRA A.C.) and Fundación Ashoka, Pátzcuaro, Michoacán, Mexico.

Ortiz-Áila, T. 2008. Caracterización de sistemas de manejo de recursos naturales. Pages 59-71 in M. Astier, Y. GalvánMiyoshi, and O. Masera, editors. Evaluación de sustentabilidad. Un enfoque dinámico y multidimensional. Sociedad Española de Agricultura Ecológica (SEAE), Centro de Investigaciones en Geografía Ambiental (CIGA), Centro de Investigaciones en Ecosistemas (CIEco-UNAM), Grupo Interdisciplinario de Tecnología Rural Apropiada (GIRA A. C.), Fundación Instituto de Agricultura Ecológica y Sustentable, and MundiPrensa, Catarroja, Valencia, Spain.

Ostrom, E. 2009. A general framework for analyzing sustainability of social-ecological systems. Science 325:419-422. http://dx.doi.org/10.1126/science.1172133

Perales, R. M. A., T. L. E. Fregoso, A. C. O. Martínez, R. V. Cuevas, M. A. Loaiza, J. J. E. Reyes, G. T. Moreno, V. O. Palacios, and R. J. L. Guzmán. 2000. Evaluación del sistema agro-silvo-pastoril del sur de Sinaloa. Pages 143-206 in O. Masera and S. López-Ridaura, editors. 2000. Sustentabilidad y sistemas campesinos: cinco experiencias de evaluación en el México rural. MundiPrensa, Grupo Interdisciplinario de Tecnología Rural Apropiada (GIRA A.C.), Programa de las Naciones Unidas para el Medio Ambiente (PNUMA), and Instituto de Ecología (IE-UNAM), Mexico City, Mexico.

Pérez-Grovas, G. V. 2000. Evaluación de la sustentabilidad del sistema de manejo de café orgánico en la Unión de Ejidos Majomut, región de los Altos de Chiapas. Pages 45-81 in O. Masera and S. López-Ridaura, editors. 2000. Sustentabilidad y sistemas campesinos: cinco experiencias de evaluación en el México rural. MundiPrensa, Grupo Interdisciplinario de 
Tecnología Rural Apropiada (GIRA A.C.), Programa de las Naciones Unidas para el Medio Ambiente (PNUMA), and Instituto de Ecología (IE-UNAM), Mexico City, Mexico.

Perfecto, I., and J. Vandermeer. 2010. The agroecological matrix as alternative to the land-sparing/agricultural intensification model. Proceedings of the National Academy of Sciences of the United States of America 107:5786-5791. http://dx.doi.org/10.1073/pnas.0905455107

Perfecto, I., J. Vandermeer, and A. Wright. 2009. Natures matrix: linking agriculture, conservation and food sovereignty. Earthscan, Sterling, Virginia, USA.

Pino-Torres, C. A. 2007. Estudio de sostenibilidad de sistemas vitícolas en transición agroecológica en la provincia de Cauquenes, Chile. Thesis. Universidad Internacional de Andalucía, Andalucía, Spain.

Poteete, A. R., M. A. Janssen, and E. Ostrom. 2010. Working together: collective action, the commons, and multiple methods in practice. Princeton University Press, Princeton, New Jersey, USA.

Prabhu, R., C. J. P. Colfer, and R. G. Dudley. 1999. Guidelines for developing, testing and selecting criteria and indicators for sustainable forest management: a C\&I developer's reference. Center for International Forestry Research (CIFOR), Bogor, Indonesia. [online] URL http://www.cifor.c giar.org/nc/online-library/browse/view-publication/publication/762. $\underline{\mathrm{html}}$

Salcedo, A., and R. García-Trujillo. 2005. Sheep production systems in the north of Granada province. Case studies. Options Méditerranéennes Serie A:101-109.

Salles, P., B. Bredeweg, and S. Araújo. 2006. Qualitative models about stream ecosystem recovery: exploratory studies. Ecological Modelling 194(1-3):80:89. http://dx.doi.org/10.1016/ j.ecolmodel.2005.10.018

Scheffer, M. 2009. Critical transitions in nature and society. Princeton University Press, Princeton, New Jersey, USA.

Smyth, A., and J. Dumanski. 1993. FESLM: an international framework for evaluating sustainable land management. World Soil Resources Reports 73. Food and Agriculture Organization of the United Nations, Rome, Italy.

Spector, M., and T. Anderson, editors. 2000. Integrated and holistic perspectives on learning, instruction and technology: understanding complexity. Kluwer Academic, Dordrecht, The Netherlands.

Speelman, E. N., and L. García-Barrios. 2010. Agrodiversity v2: an educational simulation tool to address some challenges for sustaining functional agrodiversity in agro-ecosystems. Ecological Modelling 221:911-918. http://dx.doi.org/10.1016/ j.ecolmodel.2009.12.007
Speelman, E. N., S. López-Ridaura, N. A. Colomer, M. Astier, and O. R. Masera. 2007. Ten years of sustainability evaluation using the MESMIS framework: lessons learned from its application in 28 Latin American case studies. International Journal of Sustainable Development and World Ecology 14:345-361. http://dx.doi.org/10.1080/13504500709469735

Sterman, J. D. 1994. Learning in and about complex systems. System Dynamics Review 10:291-330. http://dx.doi.org/10.1002/ sdr.4260100214

Stockle, C. O., R. I. Papendick, K. E. Saxton, G. S. Campbell, and F. K. van Evert. 1994. A framework for evaluating the sustainability of agricultural production systems. American Journal of Alternative Agriculture 9:45-50. http://dx.doi.org/1 0.1017/S0889189300005555

Sturtevant, B. R., A. Fall, D. D. Kneeshaw, N. P. P. Simon, M. J. Papaik, K. Berninger, F. Doyon, D. G. Morgan, and C. Messier. 2007. A toolkit modeling approach for sustainable forest management planning: achieving balance between science and local needs. Ecology and Society 12(2): 7. [online] URL: http://www.ecologyandsociety.org/vol12/iss2/art7

United Nations (UN). 1996. United Nations, indicators of sustainable development framework and methodologies. United Nations Sales Publication No. E.96.II.A.16. New York, New York, USA.

Valentin, A., and J. H. Spangenberg. 2000. A guide to community sustainability indicators. Environmental Impact Assessment Review 20:381-392. http://dx.doi.org/10.1016/S0 $\underline{195-9255(00) 00049-4}$

van Noordwijk, M. 2009. Linking sustainability and agroforestry science to multifunctional policy action. Pages 150-158 in Proceedings of the 6th global consortium of higher education and research for agriculture conference, 23rd - 27th November. Jomo Kenyatta University of Agriculture and Technology, Nairobi, Kenya.

Walker, B., S. Carpenter, J. Anderies, N. Abel, G. S. Cumming, M. Janssen, L. Lebel, J. Norberg, G. D. Peterson, and R. Pritchard. 2002. Resilience management in socialecological systems: a working hypothesis for a participatory approach. Ecology and Society 6(1): 14. [online] URL: http:// www.consecol.org/vol6/iss1/art14/

Waltner-Toews, D., and J. Kay. 2005. The evolution of an ecosystem approach: the diamond schematic and an adaptive methodology for ecosystem sustainability and health. Ecology and Society 10(1): 38. [online] URL: http://www.ecologyand society.org/vol10/iss 1/art38/

World Commission on Environment and Development (WCED). 1987. Our common future. Oxford University Press, New York, New York, USA. 
Young, O. R., F. Berkhout, C. Gilberto, M. Gallopin, M. A. Janssen, E. Ostrom, and S. van der Leeuwd. 2006. The globalization of socio-ecological systems: an agenda for scientific research. Global Environmental Change 16:304-316. http://dx.doi.org/10.1016/j.gloenvcha.2006.03.004 
Appendix. An example of the use of models to predict sustainability in small farming systems under conservation tillage in the Purepecha's highlands, México. The model was APSIM (Keating et al. 2003; www.apsru.gov.au). In discussions and workshops with stakeholders, scenarios were constructed comprising three levels of maize forage left over the soil -hereafter named "crop residue retention"- $(0 \%, 35 \%$ and $100 \%)$, in a maize farming system. Two sustainability attributes were explored through maize yield and crop residues modeled for 20 years under different weather sequences. Figures A-1 and A-2 show the resilience of the system, i.e., the ability to recover from an abrupt perturbation. This was tested by using a weather file with one 'stress' year of low precipitation ( $884 \mathrm{~mm} \mathrm{yr}^{-1}$ ) (year 5, the third cropping year) in a 20 year weather sequence. It can be seen that in the year of stress, the $100 \%$ crop residue retention system yields are the best of the three management types. However there is a fall of maize yield in the first cropping year after the stress year, namely year 7, after which maize yields go up again and stay higher than yields from the $0 \%$ and $35 \%$ crop residue retention systems. This fall in yields is due to nutrient immobilization. Figures B-1 and B-2, illustrate the adaptability of the systems, i.e., their ability to cope with new long-term environmental conditions, illustrated in this case through a weather sequence with decreasing amounts of precipitation. The $100 \%$ crop residue retention management shows very fluctuating yields and crop residue production between years. After a very low maize yield and a relatively low crop residue production in year 5 , the $100 \%$ regime produces higher yields and crop residues than the $0 \%$ or $35 \%$ residue retention systems (Speelman 2004).

Figure $\mathrm{A}-1$ and $\mathrm{A}-2$
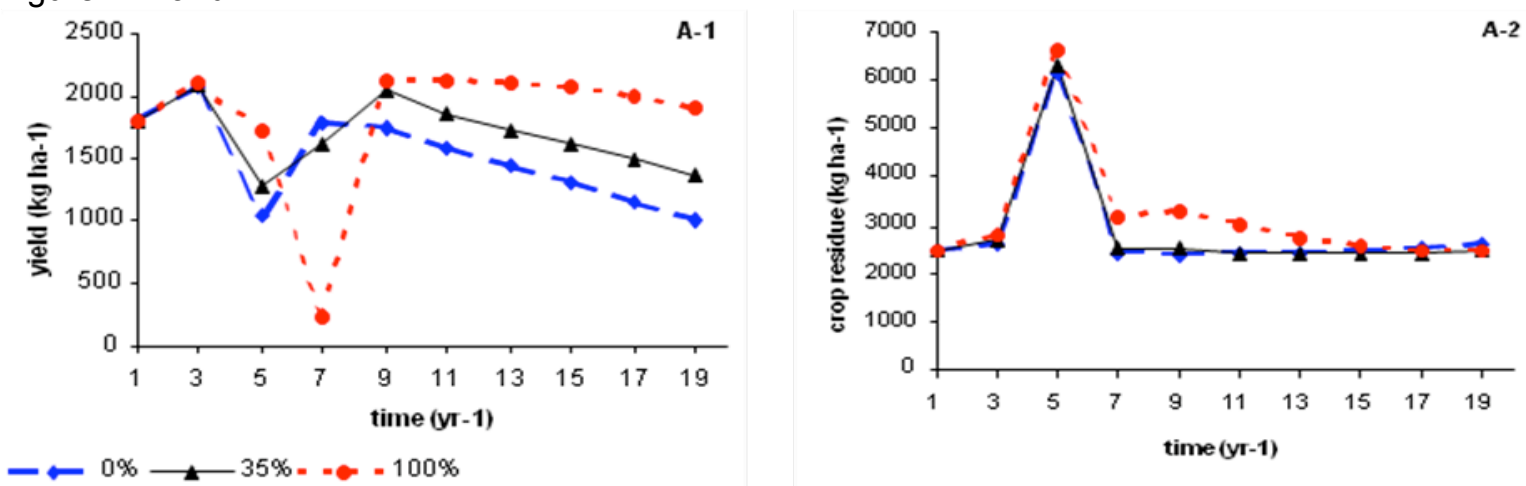

Figures B-1 and B-2
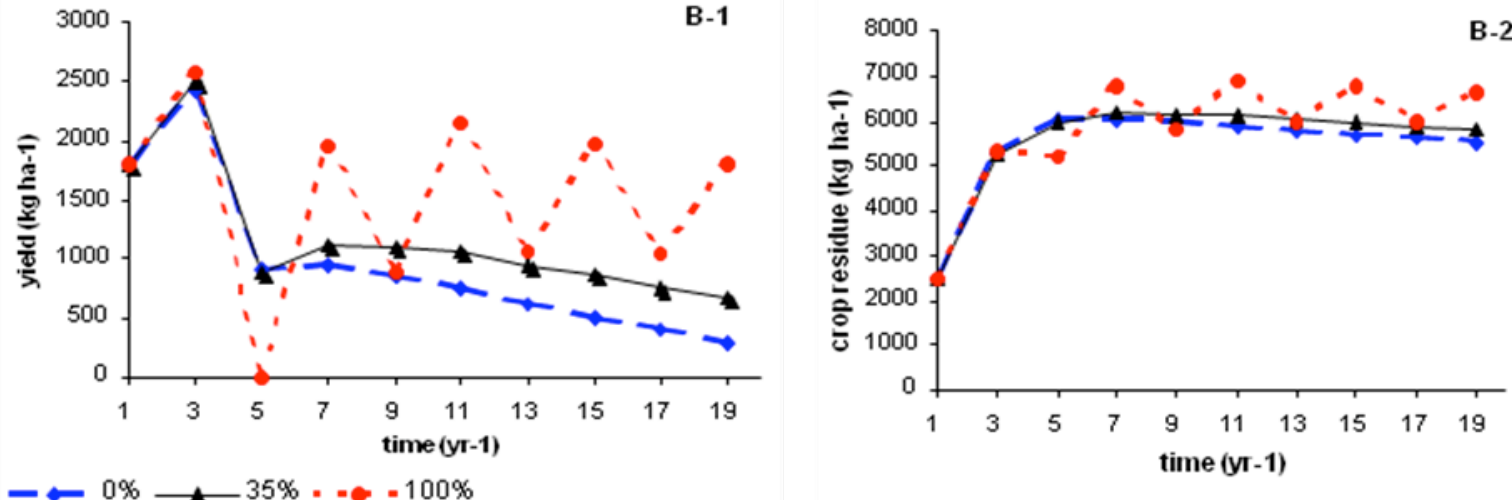